\title{
GST-Theta1 Enzyme Expression Levels in Brain Tumor and Their Relationship with the Clinical Data of the Patients
}

\section{Onur Dirican ${ }^{1 *}$, Pınar Kaygın², Sezen Yılmaz Sarıaltın³, Can Yılmaz ${ }^{4}$, Volkan Ateş ${ }^{5}$, Gülçin Güler Şimşek $^{6}$, Serpil Oğuztüzün ${ }^{7}$, Tülay Çoban ${ }^{8}$, Yusuf İzci $^{9}$}

${ }^{1}$ Kırıkkale University, Faculty of Science, Biology Department, Kırıkkale 71451,Turkey, orcid.org/0000-0003-0511-6611

${ }^{2}$ Kırıkkale University, Faculty of Science, Biology Department, Kırıkkale 71451,Turkey, orcid.org/0000-0003-0127-1753

${ }^{3}$ Ankara University, Faculty of Pharmacy, Department of Pharmaceutical Toxicology, Ankara 06560, Turkey, orcid.org/0000-0002-8387-4146

${ }^{4}$ Van Yüzüncüyll University, Faculty of Science, Molecular Biology And Genetic Department, Van 65090,Turkey, orcid.org/0000-0002-0028-6614

${ }^{5}$ Kırıkkale University, Department of Informatics, Kırıkkale 71451, Turkey, orcid.org/0000-0002-2349-0140

${ }^{6}$ University of Health Sciences, Gulhane Training and Research Hospital,Department of Pathology, Ankara 06020, Turkey, orcid.org/0000-0001-7710-4631

${ }^{7}$ Kırıkkale University, Faculty of Science, Biology Department, Kırıkkale 71451,Turkey,

orcid.org/0000-0002-5892-3735

${ }^{8}$ Ankara University, Faculty of Pharmacy, Department of Pharmaceutical Toxicology, Ankara 06560, Turkey, orcid.org/0000-0002-9696-6613

'University of Health Sciences, Gulhane Training and Research Hospital, Department of Neurosurgery, Ankara 06020, orcid.org/0000-0003-2317-3724

*Corresponding author: onurdirican@hotmail.com

Received: 30 October 2021, Accept: 20 November 2021, Published Online: 01 December 2021

\begin{abstract}
The most important drug metabolizing enzyme of the detoxification mechanism is known as Glutathione STransferase. GST enzymes may be associated with brain tumor epidemiology, clinical and demographic factors. The correlation between parameters such as changes in Glutathione S-transferase Theta1 proteins, tumor localizations, age, gender, alcohol use, smoking, chemotherapeutic/radiotherapeutic treatment status in normal and brain tumor tissues, diagnosed in neurosurgery department, were examined by immunohistochemistry. GSTTheta1 expressions were analyzed using immunostaining in samples from 149 patients diagnosed with brain tumors between 2016 and 2018. The mean age of the patient group was 49.44 years. 83 (58.45\%) patients were male. After immunohistochemical staining, GST-T1 expression was found approximately 9,46 times higher in tumor tissues than in normal tissues $(p<0.0001)$. Tumor tissues from patients who received chemotheraphy showed higher expression of GST-T1 than those who did not $(p<0,05)$. In addition, GST-T1 expression level was observed at a significantly higher level in patients younger than 60 years of age compared to patients over 60 years $(p<0.026 ; p<0.05)$. There was no statistically significant relationship between patients smoking behaviors,
\end{abstract}


alcohol consumption, tumor localization and GST-T1 expressions. It is aimed to determine the GST-T1 protein expressions and to contribute to the examination of epidemiological and prognostic factors of brain tumors by comparing them with demographic and clinical data.

Key words: Brain cancer, Immunohistochemistry, Glutation-S Transferase, GST-T1

\section{Introduction}

Recently, human, who is trying to adapt to chemical exposure, increasing stress and technological lifestyle, can provide some tolerance against all this exposure due to her metabolic structure (Courtens et al,1996; Rustoen et al.,1999). It is known that such increased exposures cause the formation of some metabolic and autoimmune diseases when the dose exceeds the tolerance threshold in metabolism. Cancer is one of these diseases (Watson and Killgore, 2016; Jörg et al., 2016). Its incidence and prevalence are increasing rapidly in our country and all over the World (Ferlay et al., 2019). Although it is in the last place in terms of incidence among cancer types, the epidemiology of brain tumor, which has a critical importance in terms of treatment and surgical intervention, is the subject of some studies today as a very important issue (Darlix et al., 2017; Barnholtz et al., 2018; Ostrom et al., 2019). This organ, which is in the first place in terms of importance in the central nervous system, is also very important in terms of being the place where all metabolic activities are controlled and the signals received from the signal transmission system are collected (Ostrom et al., 2017). Any damage to this important organ is likely to result in loss of function, partial or permanent paralysis, or death (Nabetani and Shintaku, 2018; Castello et al., 2018; Okidi et al., 2020; Sarasso et al., 2021). Therefore, current research has gained a lot of importance epidemiologically in order to improve the existing treatment methods in cancer disease or to find new treatment approaches that do not have permanent effects and have a high success rate (Mendes et al., 2018; Wu et al., 2018; Park et al., 2021). On the other hand, the most important known factor of cancer formation mechanisms is exposure to toxic substances (Wang et al., 2018; Kumar et al., 2019). It is known that chemical compounds and elements that cause cytotoxic effects and oxidative stress cause the degradation of the molecular structure and uncontrolled proliferation in the irreversible cell cycle (Ji et al., 2021). One of the tolerance mechanisms in metabolism is the xenobiotic mechanism, which proceeds with the principle of chemical reduction and removal of these toxic agents to their water-soluble state. This mechanism is also known as the detoxification mechanism (Adwas et al., 2019; Hayat et al., 2021). Glutathione S Transferases (GSTs), located in Phase II, where the most important reactions in this mechanism take place, are located in different subcellular compartments, including the cytosol, mitochondria, endoplasmic reticulum, nucleus, and plasma membrane. GSTs have important effects on cell growth, oxidative stress as well as disease progression (Raza, 2011). Oxidative stress plays a role in the pathogenesis of multifactorial diseases. GSTs are involved in the cellular detoxification process and neutralizing oxidative stress. Glutathione S-transferase Theta1 (GST-T1) is involved in cellular detoxification and is thought to have a determining effect on the susceptibility to tumor formation and disease severity (Townsend et al., 2005; Askari et al., 2018; Singh and Reindl, 2021). It can be thought that whether it is related to the expression levels of GST-T1 isoenzyme in the tissues of patients with Brain Tumors, it 
is important for a better understanding of the development of the disease. In our study, the results of GST-T1 expression, which we obtained by applying immunohistochemical method in brain tumor and normal tissues of the patients, were evaluated comparatively with some clinical and demographic data, and we aimed to reveal the relationships between the results.

\section{Material and Methods}

Clinical information about patients operated for intracranial tumors was reported by the members of the Gulhane Training and Research Hospital Neurosurgery Clinic. The archived clinical data of these patients, diagnosed between 2017 and 2019, were retrospectively evaluated. All data contains information about patient demography, histopathology and protein enzyme expressions. The written permissions were obtained from the ethics committee of the Health Sciences University Keçiören Education and Research Hospital for the entire study. All resections were performed by neurosurgeons according to a standard procedure, and clinical data were obtained by a neurosurgeon. GST-T1 were analyzed in tumor tissues of patients immunohistochemically. In addition, these markers were analyzed in normal brain tissue samples obtained from the surrounding tissue. Expression levels of the subjected proteins were classified as 0, 1,2 or 3 based on microscopic examination after immune staining.

\subsection{Histopathological examination}

A standard protocol was followed for pathological examination of resected samples. The archived, diagnosed samples of neurosurgery department and other clinical data were examined macroscopically by a pathologist in each case. From some patients, peripheral healthy tissue surrounding the tumor were also resected to be used as negative control. Only intracranial tumors (including gliomas, metastases, meningiomas, and pituitary adenomas) were included in the data set. Where more than one tumor was found, all were removed and examined. Tumor size was measured as the largest surface size. Blocks were taken to show maximum direct tumor growth of the brain. Additional blocks were specifically taken to demonstrate the relationship between the tumor and any constructive structure or tissue, and the lines of resection and normal brain tissue. Tumor grade, differentiation and degree of anaplasia were evaluated considering the nature of tumor margin (push or infiltration) and the presence and importance of brain invasion. All the pathological features analyzed were investigated in each sample and their presence or absence was recorded in detail. In the study, paired distant neighbor samples of the tumor tissue were used with a portion of the normal brain tissue surrounding the tumor site to observe the GST-T1 expression status in normal brain tissue regions to form a control group. Clinical data of patients; gender, age, smoking, alcohol use, tumor localization, chemotherapy status, radiotherapy status and ranking according to the data of the World Health Organization were included in the study as clinical parameters.

\subsection{Immunohistochemical (IHC) staining}

Tissues were fixed in 10\% buffered formalin and embedded in paraffin blocks. $4 \mu \mathrm{m}$ thick sections were cut and a section was picked to be stained with hematoxylin and eosin $(\mathrm{HE})$ to observe tissue morphology. For 
immunohistochemistry, endogenous peroxidase activity was blocked by incubating sections in $1 \%$ hygrogen peroxide $(\mathrm{v} / \mathrm{v})$ in methanol for 10 minutes at room temperature. The sections were then washed in distilled water for 5 minutes and antigen was taken in a household pressure cooker for 3 minutes using $0.01 \mathrm{M}$ citrate buffer (pH 6.0). After washing with distilled water, the sections were transferred into $0.05 \mathrm{M} \mathrm{Tris-HCl}(\mathrm{pH} \mathrm{7.6)}$ containing $0.15 \mathrm{M}$ sodium chloride (TBS). Sections were incubated with Super Block (streptavidin / HRP complex [SHP125]; ScyTek Laboratories USA) to prevent nonspecific background staining at room temperature for 10 minutes. Sections were then coated with primary antibodies diluted 1:50 for anti-GSTT1, at $4{ }^{\circ} \mathrm{C}$, a hour (anti GST-Theta1 from Cloud Clone Corp. TX, USA). After washing for 15 minutes in TBS, the sections were incubated for biotinylated link antibody followed by SHP125 at room temperature. Diaminobenzidine was used to visualize peroxidase activity in tissues. Nuclei were lightly counterstained with hematoxylin, and then the sections were dehydrated and mounted. Both positive and negative controls were included in each study. Light microscopy of immunohistochemically stained sections was performed by patients' clinical information, other histopathological data or pathologist unaware of survival. Tissue nuclei from the central part of the tumor and from the invasive front were evaluated separately in each sample, such as the presence of nuclear and cytoplasmic staining in tumor epithelial cells. The staining intensity was graded as 0 (no staining), 1 (poor staining), 2 (medium staining) or 3 (strong staining).

\subsection{Statistical analysis}

All statistical analysis was done using SPSS v25.0. Continuous data were expressed as mean \pm standart error of mean (SEM) and categorical was number ( $n$ ) and percentage (\%). Staining scores were calculated according to the intensity of positively stained tumor tissues. Staining intensity was graded as; 0: negative expression, +1 weak expression, +2 : moderate expression, +3 : strong expression. The normality of data was assessed using the Shapiro Wilk and Kolmogorov-Smirnov tests. Levene variance test was also performed. Mann Whitney- $U$ was used to examine the differences between two independent groups as a non-parametric test. Independent Samples-Kruskal Wallis-H test following Bonferroni correction was used to assess the differences between more than two independent groups with non-normal distributions. Spearman's rank correlation coefficients were computed for correlation analyses. A p-value of less than 0,05 was accepted as statistically significant.

\section{Results}

The preparative samples obtained as a result of the GST-T1 marker application with the immunohistochemical method were examined by a specialist pathologist by microscopy and expression scoring was performed. General images of some samples obtained microscopically are as in Figure 1. 

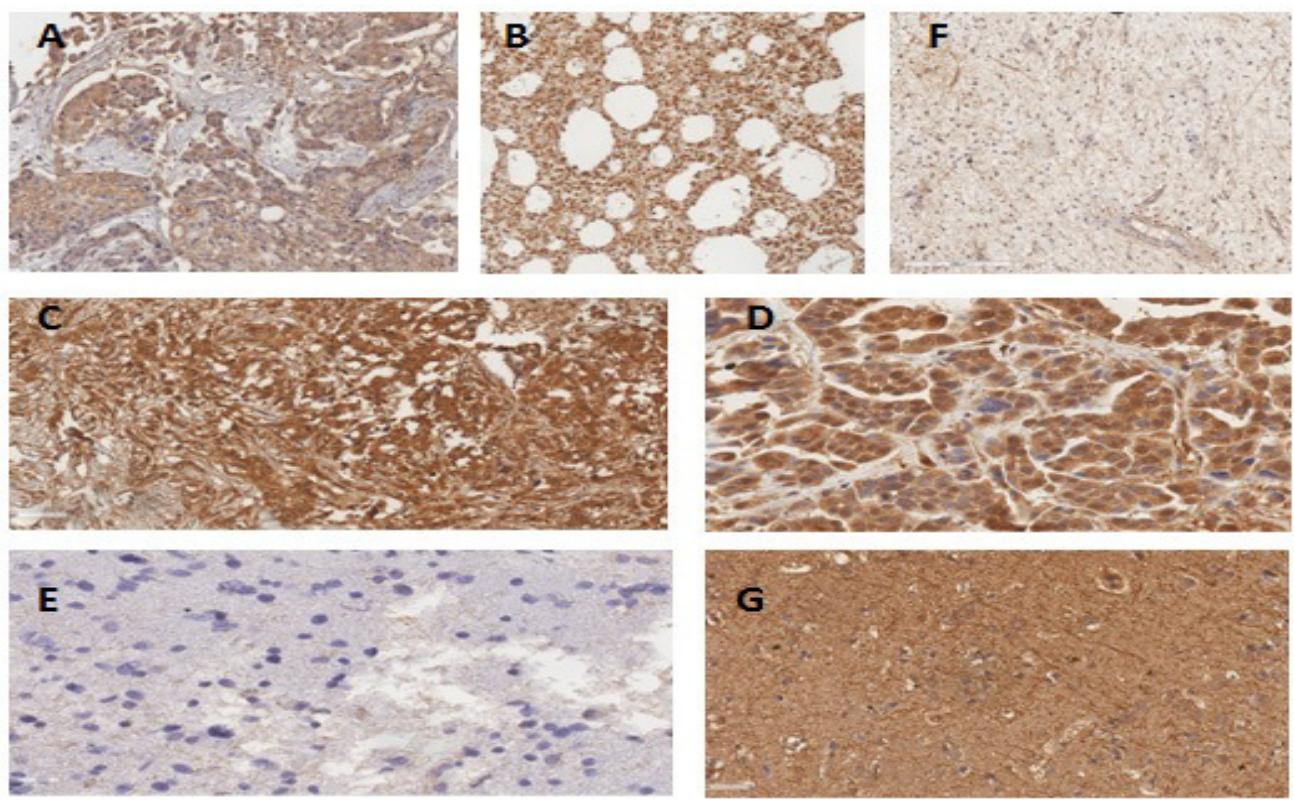

Figure 1. (A) Shows GST-T1 (+1) positive nuclei which are stained brown in tumor tissue (x4). (B) Shows GST-T1 (+2) positive nuclei which are stained brown in tumor tissue $(x 8)$. (C) Shows GST-T1 (+3) positive nuclei which are stained brown in tumor tissue $(x 10)$. (D) Shows GST-T1 (+3) positive nuclei which are stained brown in tumor tissue (x40). (E) Shows GSTT1 (-) negative nuclei which are not stained with a colour in normal tissue $(x 40)$. (F) Shows GST-T1 (+1) positive nuclei which are stained brown in normal tissue (x20). (G) Shows GST-T1 (+2) positive nuclei which are stained brown in normal tissue $(x 40)$.

Demographic data such as gender, age, smoking status, alcohol consumption are shown in Table 1. 149 brain tumor and normal tissue specimens were analyzed in this study. The average age of the patients was 49.44 at a range of 6 to 83 years. Female patients comprised $41.7 \%$ of the samples, while $58.3 \%$ were male. A total of $30.2 \%$ of patients were smokers, and $10.1 \%$ of drank alcohol.

Table 1. Patients' demographic data.

\begin{tabular}{|c|c|}
\hline Demographic data & $\mathrm{n}(\%)$ \\
\hline Gender & $62(41.7 \%)$ \\
\hline Female & $87(58.3 \%)$ \\
\hline Male & \\
\hline Age (years) & $96(64.43 \%)$ \\
\hline$<60$ & $53(35.57 \%)$ \\
\hline$\geq 60$ & \\
\hline Smoking & $45(30.2 \%)$ \\
\hline Yes & $103(69.1 \%)$ \\
\hline No & $1(0.7 \%)$ \\
\hline Missing & $15(10 \%)$ \\
\hline Alcohol comsumption & $133(89.3 \%)$ \\
\hline Yes & $1(0.7 \%)$ \\
\hline Missing & \\
\hline
\end{tabular}

$\mathrm{n}$ : Number, $\% 100$ percentage of total population 
Clinical data including the characteristics of the tumors, radiotherapy and chemotherapy status, information about surgical procedures such as number, part, resection margin, lesion localization are exhibited in Table 2. According to clinical data, 55 patients (36.9\%) received radiotherapy and $32(21.5 \%)$ were chemotherapy. 113 patients $(75.8 \%)$ were operated on once. Most tissue was collected from the frontal lobe with $28.9 \%$ following by parietal lob with $13.4 \%$.

Table 2. Patients' clinical data.

\begin{tabular}{|c|c|}
\hline Clinical data & $\mathrm{n}(\%)$ \\
\hline \multicolumn{2}{|l|}{ Chemotherapy } \\
\hline Yes & $32(21.4 \%)$ \\
\hline No & $116(77.9 \%)$ \\
\hline Missing & $1(0.7 \%)$ \\
\hline \multicolumn{2}{|l|}{ Radiotherapy } \\
\hline Yes & $55(36.9 \%)$ \\
\hline No & $92(61.7 \%)$ \\
\hline Missing & $2(1.4 \%)$ \\
\hline \multicolumn{2}{|l|}{ Number of surgery } \\
\hline 1.00 & $113(75.8 \%)$ \\
\hline 2.00 & $30(20.1 \%)$ \\
\hline 3.00 & $2(1.3 \%)$ \\
\hline 4.00 & $1(0.7 \%)$ \\
\hline 5.00 & $1(0.7 \%)$ \\
\hline 7.00 & $1(0.7 \%)$ \\
\hline 10.00 & $1(0.7 \%)$ \\
\hline \multicolumn{2}{|l|}{ Part } \\
\hline Bilateral & $1(0.7 \%)$ \\
\hline Middle & $24(16.1 \%)$ \\
\hline Left & $66(44.3 \%)$ \\
\hline Right & $58(38.9 \%)$ \\
\hline \multicolumn{2}{|l|}{ Resection margin } \\
\hline Gross total & $91(61.1 \%)$ \\
\hline Parsiel & $5(3.4 \%)$ \\
\hline Subtotal & $52(34.8 \%)$ \\
\hline Missing & $1(0.7 \%)$ \\
\hline \multicolumn{2}{|l|}{ Lesion localization } \\
\hline Frontal & $48(32.6 \%)$ \\
\hline Parietal & $26(17.3 \%)$ \\
\hline Temporal & $22(14.7 \%)$ \\
\hline Cerebellar & $18(12 \%)$ \\
\hline Occipital & $10(6.7 \%)$ \\
\hline Other & $25(16.7 \%)$ \\
\hline \multicolumn{2}{|l|}{ Pathology } \\
\hline Glial tumor & $46(30.8 \%)$ \\
\hline Metastasis & $42(28.2 \%)$ \\
\hline
\end{tabular}




\begin{tabular}{|l|c|}
\hline Meningioma & $32(21.6 \%)$ \\
\hline Pituitary Adenoma & $12(8.0 \%)$ \\
\hline Radiation Necrosis & $3(2.0 \%)$ \\
\hline Schwannoma & $3(2.0 \%)$ \\
\hline Cavernoma & $2(1.3 \%)$ \\
\hline Medulloblastoma & $2(1.3 \%)$ \\
\hline Central neurocytoma & $2(1.3 \%)$ \\
\hline Demyelinating disease & $1(0.7 \%)$ \\
\hline DNET & $1(0.7 \%)$ \\
\hline Inflammation & $1(0.7 \%)$ \\
\hline Craniopharyngioma & $1(0.7 \%)$ \\
\hline Lhermitte Duclos Disease & $1(0.7 \%)$ \\
\hline
\end{tabular}

n: Number, $100 \%$ percentage of total population

Demographic data and general representation of clinical data of 149 patients with brain tumors included in our study are shown in Figure 2 and Figure 3.

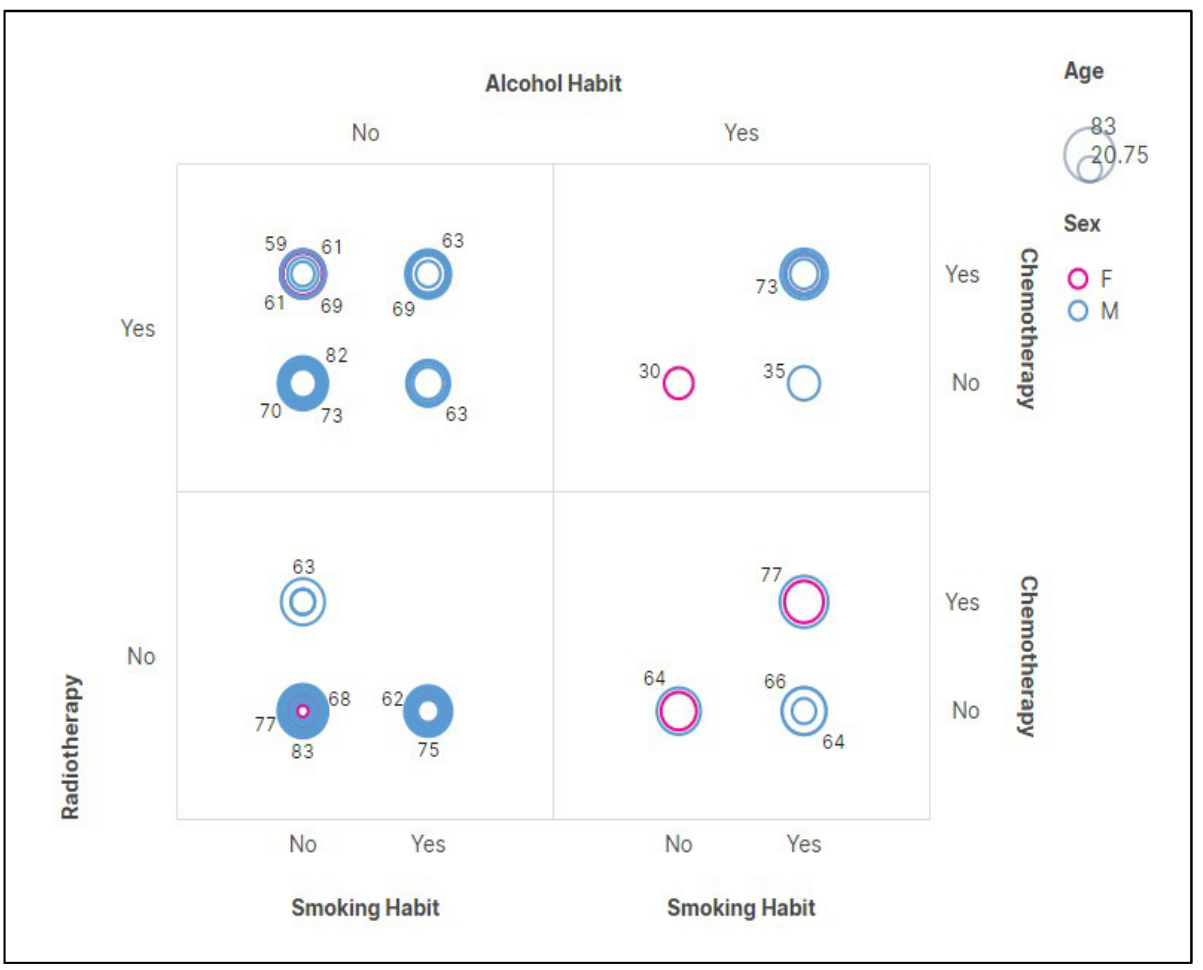

Figure 2. Demographic information distribution of patients according to Gender, age, alcohol and cigarette use, radiotherapy and chemotherapy treatment status. 


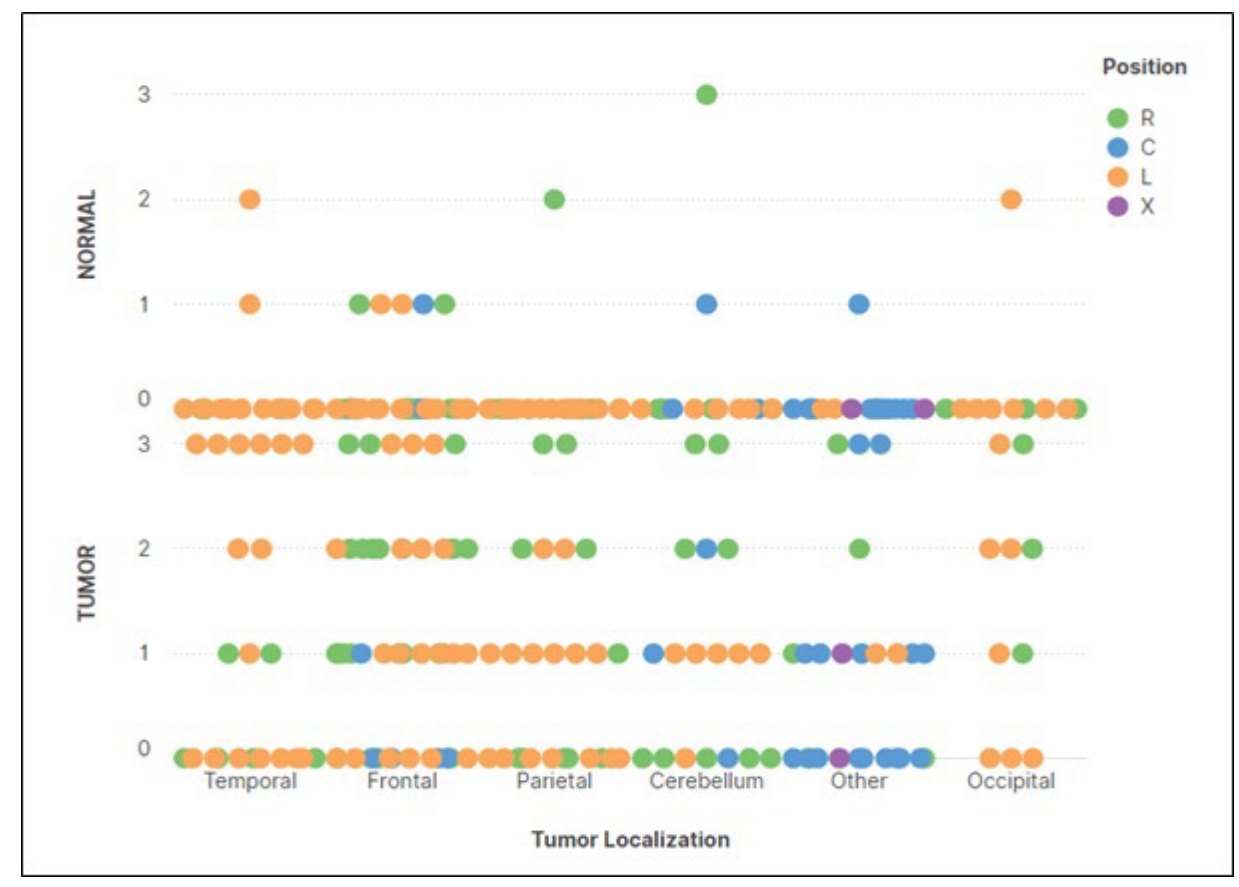

Figure 3. Distribution of the rates of GST-T1 enzyme expression in normal and tumor tissues, depending on the main localizations of the brain.

GST-T1 expression profiling of brain tumor and normal tissues are presented in Table 3. $28.19 \%$ of tumor tissues exhibited weak expression, while $5.37 \%$ of normal tissues were. $16.78 \%$ of tumor tissues and $2.01 \%$ of normal tissues showed moderate expression. $14.09 \%$ of tumor tissues and $0.67 \%$ of normal tissues showed strong expression. Tumor tissues presented almost 9.46 fold higher GST-T1 expression than normal tissues. Tumor tissues showed significantly greater expression than normal tissues $(p<0.0001)$.

Table 3. GST-T1 expression profiling of brain tumor and normal tissues.

\begin{tabular}{|c|c|c|}
\hline \multirow{2}{*}{ Staining Scores } & \multicolumn{3}{|c|}{ GST-T1 } \\
\cline { 2 - 3 } & Tumor & Normal \\
$\mathbf{0}$ & $61(40.94 \%)$ & $137(91.95 \%)$ \\
\hline $\mathbf{1}$ & $42(28.19 \%)$ & $8(5.37 \%)$ \\
\hline $\mathbf{2}$ & $25(16.78 \%)$ & $3(2.01 \%)$ \\
\hline $\mathbf{3}$ & $21(14.09 \%)$ & $1(0.67 \%)$ \\
\hline Total & $149(100 \%)$ & $149(100 \%)$ \\
\hline Mean & $1.04 \pm 0.09 \mathrm{a}$ & $0.11 \pm 0.04^{\mathrm{a}}$ \\
\hline T/N & $(0-3)^{\mathrm{b}}$ & $(0-3)^{\mathrm{b}}$ \\
p-value & \multicolumn{2}{|c|}{$\mathbf{9 . 4 6}$} \\
\hline
\end{tabular}

Staining scores were calculated according to the intensity of positively stained tissues.

Staining intensity was graded as; 0 : negative expression, +1 : weak expression,

+2 : moderate expression, +3 : strong expression a: mean $\pm \mathrm{sem} ; \mathrm{b}$ : minimum and maximum staining intensity $p$ values less than 0,05 were considered statistically significant 
GST-T1 expressions in brain tumor and normal tissues according to patients' demographic characteristics were exhibited in Table 4. These demographic characteristics are age, sex, smoking, and alcohol consumption status. GST-T1 expression in tumor tissues taken from patients younger than 60 years of age was found to be higher than those of 60 years and older, significantly $(p<0.026 ; p<0.05)$. No significant differences were observed in GST-T1 expression in regards to gender, as well as smoking and alcohol consumption habits $(p>0.05)$.

Table 4. GST-T1 expressions in brain tumor and normal tissues according to patients' demographic characteristics.

\begin{tabular}{|c|c|c|}
\hline \multirow{2}{*}{ Variable } & \multicolumn{2}{|c|}{ GST-T1 } \\
\hline & Tumor & Normal \\
\hline \multicolumn{3}{|l|}{ Age } \\
\hline$<60$ & $\begin{array}{c}1.19 \pm 0.11^{a} \\
(0-3)^{b}\end{array}$ & $\begin{array}{c}0.16 \pm 0.05^{a} \\
(0-3)^{b}\end{array}$ \\
\hline$\geq 60$ & $\begin{array}{c}0.77 \pm 0.13^{a} \\
(0-3)^{b}\end{array}$ & $\begin{array}{c}0.04 \pm 0.03^{a} \\
(0-1)^{b}\end{array}$ \\
\hline$p$-value & 0.026 & 0.146 \\
\hline \multicolumn{3}{|l|}{ Gender } \\
\hline Female & $\begin{array}{c}1.02 \pm 0.15^{\mathrm{a}} \\
(0-3)^{\mathrm{b}}\end{array}$ & $\begin{array}{c}0.08 \pm 0.06^{a} \\
(0-3)^{b}\end{array}$ \\
\hline Male & $\begin{array}{c}1.06 \pm 0.11^{a} \\
(0-3)^{b}\end{array}$ & $\begin{array}{c}0.13 \pm 0.04^{a} \\
(0-2)^{b}\end{array}$ \\
\hline$p$-value & 0.638 & 0.107 \\
\hline \multicolumn{3}{|l|}{ Smoking } \\
\hline Yes & $\begin{array}{c}1.04 \pm 0.16^{a} \\
(0-3)^{b}\end{array}$ & $\begin{array}{c}0.13 \pm 0.06^{a} \\
(0-2)^{b}\end{array}$ \\
\hline No & $\begin{array}{c}1.05 \pm 0.11^{a} \\
(0-3)^{b}\end{array}$ & $\begin{array}{c}0.11 \pm 0.04^{a} \\
(0-3)^{b}\end{array}$ \\
\hline \multicolumn{3}{|l|}{ Alcohol consumption } \\
\hline Yes & $\begin{array}{c}0.93 \pm 0.28^{a} \\
(0-3)^{b}\end{array}$ & - \\
\hline No & $\begin{array}{c}1.06 \pm 0.09^{a} \\
(0-3)^{b}\end{array}$ & $\begin{array}{c}0.13 \pm 0.04^{a} \\
(0-3)^{b}\end{array}$ \\
\hline$p$-value & 0.630 & 0.227 \\
\hline
\end{tabular}

Staining scores were calculated according to the intensity of positively stained tissues. Staining intensity was graded as; 0 : negative expression, +1 weak expression, +2 : moderate expression, +3 : strong expression a: mean \pm sem; $b$ : minimum and maximum staining intensity. $p$ values less than 0,05 were considered statistically significant.

GST-T1 expressions in brain tumor and normal tissues depending on patients' clinical characteristics are shown in Table 5. These demographic characteristics are radiotherapy, chemotherapy, lesion localization, and post-op status. Tumor tissues taken from the patients treated with chemotherapy possessed significantly higher GST-T1 expression than those who did not receive chemotherapy $(p<0.05)$. There are no statistically significant differences between groups depending on radiotherapy and lesion localization ( $p>0.05)$. GST-T1 expressions of tumor tissues taken from post-op exitus patients were statistically greater than that of alive patients $(p=0.004$; $p<0.05)$. 
Table 5. GST-T1 expressions in brain tumor and normal tissues according to patients' clinical characteristics.

Variable

GST-T1

\begin{tabular}{|c|c|c|}
\hline & Tumor & Normal \\
\hline \multicolumn{3}{|l|}{ Chemotherapy } \\
\hline Yes & $\begin{array}{c}1.36 \pm 0.19^{a} \\
(0-3)^{b}\end{array}$ & $\begin{array}{c}0.06 \pm 0.06 \mathrm{a} \\
(0-2)^{\mathrm{b}}\end{array}$ \\
\hline No & $\begin{array}{c}0.95 \pm 0.10^{\mathrm{a}} \\
(0-3)^{\mathrm{b}}\end{array}$ & $\begin{array}{c}0.13 \pm 0.04^{a} \\
(0-3)^{b}\end{array}$ \\
\hline$p$-value & 0.041 & 0.245 \\
\hline \multicolumn{3}{|l|}{ Radiotherapy } \\
\hline Yes & $\begin{array}{c}1.11 \pm 0.13^{a} \\
(0-3)^{b}\end{array}$ & $\begin{array}{c}0.14 \pm 0.07 a \\
(0-3)^{b}\end{array}$ \\
\hline No & $\begin{array}{c}1.00 \pm 0.12^{\mathrm{a}} \\
(0-3)^{\mathrm{b}}\end{array}$ & $\begin{array}{c}0.10 \pm 0.04^{a} \\
(0-2)^{b}\end{array}$ \\
\hline$p$-value & 0.358 & 0.781 \\
\hline \multicolumn{3}{|c|}{ Lesion localization } \\
\hline Frontal & $\begin{array}{c}1.30 \pm 0.15^{a} \\
(0-3)^{b}\end{array}$ & $\begin{array}{c}0.09 \pm 0.04^{a} \\
(0-1)^{b}\end{array}$ \\
\hline Parietal & $\begin{array}{c}0.75 \pm 0.75^{a} \\
(0-3)^{b}\end{array}$ & - \\
\hline Cerebellar & $\begin{array}{c}1.00 \pm 0.28^{a} \\
(0-3)^{b}\end{array}$ & $\begin{array}{c}0.27 \pm 0.21 a \\
(0-3)^{b}\end{array}$ \\
\hline Temporal & $\begin{array}{c}1.06 \pm 0.31^{a} \\
(0-3)^{b}\end{array}$ & $\begin{array}{c}0.12 \pm 0.12^{a} \\
(0-2)^{b}\end{array}$ \\
\hline Other & $\begin{array}{c}0.90 \pm 0.12^{\mathrm{a}} \\
(0-3)^{\mathrm{b}}\end{array}$ & $\begin{array}{c}0.10 \pm 0.05^{a} \\
(0-2)^{b}\end{array}$ \\
\hline$p$-value & 0.254 & 0.880 \\
\hline \multicolumn{3}{|l|}{ Post-op status } \\
\hline Alive & $\begin{array}{c}0.86 \pm 0.10^{\mathrm{a}} \\
(0-3)^{\mathrm{b}}\end{array}$ & $\begin{array}{c}0.13 \pm 0.05^{a} \\
(0-3)^{b}\end{array}$ \\
\hline Ex & $\begin{array}{c}1.38 \pm 0.16^{a} \\
(0-3)^{b}\end{array}$ & $\begin{array}{c}0.08 \pm 0.05^{a} \\
(0-2)^{b}\end{array}$ \\
\hline$p$-value & 0.004 & 0.452 \\
\hline
\end{tabular}

Staining scores were calculated according to the intensity of positively stained tissues. Staining intensity was graded as; 0 : negative expression, +1 weak expression, +2 : moderate expression, +3 : strong expression a: mean \pm sem; $b$ : minimum and maximum staining intensity. $p$ values less than 0,05 were considered statistically significant.

Correlation analysis was performed between GST-T1 expression levels and the other continuous variables. No significant correlation was found between the variables $(p>0.05)$.

\section{Discussion}

In order to understand the metabolism of xenobiotics in the detoxification mechanism, the effects of these enzymes on drug resistance, free oxygen radicals, oxidative stress and carcinogenesis have been the subject of research in the literature.

Murray and Burke (1995) reported that the best method for determining drug metabolizing and detoxifying enzymes in the cell content is the immunohistochemical method. 
In a 2003 study to determine the expression of p125 in paraffin blocks of tumor tissues, 18 different colorectal liver metastases as well as 24 pairs of primary colorectal carcinoma and colorectal liver metastases were examined using immunohistochemical tests using monoclonal anti-FAK 4.47. They stated that there was high p125 FAK expression in normal colorectal mucosa and both primary colorectal tumors and liver metastatic tumors (Lark et al., 2003).

In a study on GST-P isoenzyme expression and carcinogenicity in 1993, GST-P expression level in liver cells of 194 pesticides (Diethylnitrosamine, S-tributylphosphorotithioate, Vinclozolin, Chlorobenzilate, Tecnazene, Isoproturon, Dicloran) sample applied at various concentrations was controlled by immunohistochemical method. There was no difference in the expression of GST-P after administration, which could lead to a tendency to carcinogenicity. It was also reported that no significant difference was observed between the chemicals applied (Hoshiya et al., 1993).

In another study, in which the expression levels of GST isozymes alpha, mu and pi were examined by immunohistochemical method in 51 patients with head and neck tumors treated with chemotherapy, it was stated that the cytotoxic effects of chemotherapy may cause irreversible damage. It was observed that the blind scores obtained with the GST-P antibody gave the same result as the pan-specific antibody in all cases except one (Nishimura et al., 1996).

In a study conducted in 2018 with 55 patients diagnosed with intracranial brain tumor by immunohistochemical method, cytochrome p450 (CYO) and GST-P1 enzyme expression levels were examined. A significant increase in enzyme expression was detected. In addition, the highest GST and CYP enzyme levels were observed in pituitary adenomas. Therefore, they reported that these tumor types are able to metabolize more drugs than other intercranial tumors (Kural et al., 2018).

In 2013, a study with mouse asthma models emphasized the importance of GSTs in the detoxification of ROS compounds and toxic compounds and examined their correlation with asthma. They showed increased expression of GST especially in the group treated with OVA and PBS. It was noted that mRNA expression for GST-P1 was higher than for PBS in patients treated with OVA. It has been reported that there is no significant difference between GST-P1, GST-T1, GST-M1 in terms of expression levels. It has also been noted that increased oxidative stress causes upregulation of GSTs (Sohn et al., 2013).

In the case diagnosed with breast cancer in 2003, 67 (58\%) samples were GST-P and $43(37 \%)$ cases were Bcl2 positive. When examined by double immunofluorescence labeling, significant accumulation of GST-P marker was observed in the nuclei of cancer cells (Huang et al., 2003).

GST Omega expression levels were investigated in various human tissues such as glial, breast myoepithelial, colon neuroendocrine cells, fetal myocytes, hepatocytes, biliary epithelial cells, pancreatic ductal epithelium, Hoffbauer cells in the placenta, $C$ cells in the thyroid tissue, and follicular cells. It has been reported that the condensation in the nucleus depending on the expression in the cells is similar to the known expression states of other GST isozymes, as well as in GST Omega. It has been suggested that the functions of GST Omega that differ from other isozymes should be revealed (Yin et al., 2003). 
In another study examining the resistance of glutathione group compounds to chemotherapy-active agents used in brain tumors in the literature, they reported that the resistance was more pronounced in irregular isozyme and evenly distributed metabolism (Backos et al., 2012).

Expression levels of GST isozymes in kidney cells were investigated by immunohistochemistry method in 1989. Heterogeneous and multifocal were observed in all 12 kidney tissues using GST-alpha, GST-pi and GST-mu. It has also been stated that this situation may be associated with carcinogenesis (Harrison et al., 1989).

The chemoresistance of GST-pi, GST-mu and GST-alpha isozymes was followed in a study by grafting A549 non-small cell lung cell lines on mouse models. As a result of the findings of the study, it was stated that the A549 xenograft model could be used to determine which of the drugs used in hospitals plays a more active role (Mathieu et al., 2004).

In another study comparing CYP1A1 and GSTP1 enzyme expression levels in brain tumor tissues, Western blot and Elisa techniques were used in a study conducted with 36 patients with brain tumors and a control group in the Pakistani population. CYP1A1 expression was observed 4 times higher in tumor tissues than in normal tissues. GST-P expression level was found to be lower in tumor tissues than in normal tissues (Wahid et al., 2013).

GST-P expression levels after exposure to Cytokeratin, which is the subject of another study in the literature, were examined by SELDI-TOF mass spectrophotometer and confirmed by immunohistochemical method and qPCR. CK8 phosphorylation at Ser73 and Ser431 has been reported to be strongly associated with hepatocellular carcinoma and carcinogenesis. Strong expression was also expressed at the mRNA level in validation studies performed in QPCR. GST-P has been shown to be strongly induced in proliferation and tumorfocused regions (Kakehashi et al., 2009).

GST-alpha, GST-mu and GST-pi by immunohistochemical method at different stages of human ovarian cells (different stages of menstrual cycle and pregnancy and after menopause) due to intracellular transport of steroids and their drug metabolizing roles enzyme expression levels were examined. Different expression levels were observed in different stages of the ovarian cell. However, it has been observed to be significantly associated with the GST-dependent 5,3-ketosteroidisomerase, which catalyzes the conversion of pregnenolone to progesterone and dehydroepiandrosterone to androstenedione (Rahilly et al.,1991).

The expression levels of glutathione-related compounds of platinum-based chemotherapy treatments used in head and neck tumors were the subject of another study. Immunohistochemistry and in situ hybridization techniques were used in the study conducted in 51 patients. It has been observed that patients with a low GST score are 4.7 times more likely to respond to chemotherapy treatment than patients with a high GST score (Nishimura et al., 1998).

A study in 1997, the expression level of GST-P enzyme in benign and malignant prostate tissues was examined by immunohistochemical method. In the study conducted with 69 benign and 44 malignant prostate tissues, it was detected in basal cells in benign tissues at a rate of $67 \%$. It has been reported that weak positive expression was observed in $94 \%$ of other epithelial cells (Cookson et al., 1997). 
GST-P enzyme activity in endocrine cells in colorectal cancer tissues was investigated. It has been determined that cases with GST-P-expressing endocrine cells in primary tumor tissues have a worse prognosis after surgical intervention than those with GST-P negative endocrine cells (Gulubova and Vlaykova, 2010).

Expression levels of GST-P enzyme in human glioma cells were compared with Pgp, MRP1, MRP3, MRP5 enzymes. MRP1, MRP5 and GST-P enzyme expressions were predominantly observed in endothelial cells and drug resistance was reported to be high in these cases with high enzyme activity (Calatozzolo et al., 2010).

In 2008, GST-alpha, GST-pi and GST-mu enzyme expression levels in the brain tissues of epileptic patients were investigated. GST-alpha expression was not observed in the study conducted with 32 epileptic patients and 8 normal control groups. Expression of GST-mu was observed in $63 \%$ of the control group and $53 \%$ of the epileptic samples. It was determined that GST-pi expression was observed at a rate of $50 \%$ in the control group in endothelial and glial cells, while it was synthesized at a rate of $66 \%$ in epileptic cells (Shang et al., 2008).

GST-P enzyme expressions in 150 human glioma cells were investigated by immunohistochemical method. While a gradual increase in GST-P expression was observed, no significant association was found with age, gender, or other clinical data (Wang et al., 2017).

The data obtained in our study were made by applying the method of immunohistochemistry, which is the preferred method in other studies in the literature, on brain tumor tissues. From these data, the GST-T1 expression level observed in tumor tissues was found to be quite high compared to normal tissues. In addition, significantly higher expression levels were found in individuals over 60 years of age and in patients receiving chemotherapy treatment.

\section{Conclusion}

The most important known role of phase II enzymes, which play a role in detoxification and drug metabolism mechanism, is to detoxify chemotherapeutic agents used in cancer treatment. In this direction, the fact that the data in this section obtained in our study yield similar results causes us to evaluate this role of GST enzymes with its known contribution. We think that the increase in GST-T1 expression in metabolic processes related to carcinogenesis in elderly individuals will be a factor in the diagnosis and epidemiological understanding of brain tumors. In addition, we suggest the importance of the necessity of clarifying whether these enzyme expressions are affected by damages at the genetic level or whether it is genetically controlled by other studies to be carried out.

\section{Acknowledgements}

The studies were carried out in the Kırıkkale University, Department of Biology, Tissue Research Laboratory. I thank all authors. Also, we thank the University of Health Sciences, Gulhane Training and Research Hospital, Department of Pathology and Department of Neurosurgery and Ankara University, Faculty of Pharmacy, Department of Pharmaceutical Toxicology. 


\section{Conflicts of Interests}

Authors declare that there is no conflict of interests

\section{Ethics committee permission}

Ethics committee approval for this scientific research study was obtained from the Health Sciences University Ethics Committee with the decision numbered 2012-KAEK-15/1810.

\section{Funding}

We thank the Kırıkkale University Scientific Research and Projects Department (Project no. 2019/178) for funding this research.

\section{References}

Adwas, A. A., Elsayed, A. S. I., \& Azab, A. E. (2019). Oxidative stress and antioxidant mechanisms in human body. Journal of Applied Biotechnology and Bioengineering, 6(1), $43-47$. https://doi.org/10.15406/jabb.2019.06.00173

Askari, H., Rajani, S. F., Poorebrahim, M., Haghi-Aminjan, H., Raeis-Abdollahi, E., \& Abdollahi, M. (2018). A glance at the therapeutic potential of irisin against diseases involving inflammation, oxidative stress, and apoptosis: An introductory review. Pharmacological Research, 129, 44-55. https://doi.org/10.1016/j.phrs.2018.01.012

Backos, D. S., Franklin, C. C., \& Reigan, P. (2012). The role of glutathione in brain tumor drug resistance. Biochemical Pharmacology, 83(8), 1005-1012. https://doi.org/10.1016/j.bcp.2011.11.016

Barnholtz-Sloan, J. S., Ostrom, Q. T., \& Cote, D. (2018). Epidemiology of brain tumors. Neurologic Clinics, 36(3), 395-419. https://doi.org/10.1016/j.ncl.2018.04.001.

Calatozzolo, C., Gelati, M., \& Ciusani, E. (2005). Expression of drug resistance proteins Pgp, MRP1, MRP3, MRP5 AND GST-חin human glioma. Journal of Neuro-Oncology, 74, 113-121. https://doi.org/10.1007/s11060-004-6152-7

Castello, L. M., Salmi, L., Zanotti, I., Gardino, C. A., Baldrighi, M., Settanni, F., \& Avanzi, G. C. (2018). The increase in copeptin levels in mild head trauma does not predict the severity and the outcome of brain damage. Biomarkers in Medicine, 12(6), 555-563. https://doi.org/10.2217/bmm-2018-0041.

Cookson, M. S., Reuter, V. E., Linkov, I., \& Fair, W. R. (1997). Glutathione S-transferase PI (GST-pi) class expression by immunohistochemistry in benign and malignant prostate tissue. The Journal of Urology, 157(2), 673-676. https://doi.org/10.1016/S0022-5347(01)65248-0

Courtens, A. M., Stevens, F. C., Crebolder, H. F., \& Philipsen, H. (1996). Longitudinal study on quality of life and social support in cancer patients. Cancer Nursing, 19(3), 162-169. https://doi.org/10.1097/00002820$199606000-00002$.

Darlix, A., Zouaoui, S., Rigau, V., Bessaoud, F., Figarella-Branger, D., Mathieu-Daudé, H., Trétarre, B., Bauchet, F., Duffau, H., Taillandier, L., \& Bauchet, L. (2017). Epidemiology for primary brain tumors: a nationwide 
population-based study. Journal of Neuro-Oncology, 131(3), 525-546. https://doi.org/10.1007/s11060-0162318-3.

Ferlay, J., Colombet, M., Soerjomataram, I., Mathers, C., Parkin, D. M., Piñeros, M., Znaor, A., \& Bray, F. (2019). Estimating the global cancer incidence and mortality in 2018: GLOBOCAN sources and methods. International Journal of Cancer, 144(8), 1941-1953. https://doi.org/10.1002/ijc.31937.

Gulubova, M., \& Vlaykova, T. (2010). Expression of the xenobiotic- and reactive oxygen species-detoxifying enzymes, GST-pi, Cu/Zn-SOD, and Mn-SOD in the endocrine cells of colorectal cancer. International Journal of Colorectal Disease, 25(12), 1397-1405. https://doi.org/10.1007/s00384-010-1041-3

Harrison, D. J., Kharbanda, R., Bishop, D., McLelland, L. I., \& Hayes, J. D. (1989). Glutathione S-transferase isoenzymes in human renal carcinoma demonstrated by immunohistochemistry. Carcinogenesis, 10(7), 1257-1260. https://doi.org/10.1093/carcin/10.7.1257

Hayat, B., Yavuz, M. S., Şahin, M. E., Dirican, O., Yılmaz, S., Yılmaz, C., Yıldıım, I., Çoban, T., Güler Şimşek, G. \& Oğuztüzün, S. (2021). Kronik obstrüktif akciğer hastalığında Glutatyon-S-Transferaz Mu1 ve Teta1 polimorfizmlerinin rolü. Journal of Faculty of Pharmacy of Ankara University, 45 (1), 41-56. https://doi.org/10.33483/jppau.839530

Hoshiya, T., Hasegawa, R., Hakoi, K., Cui, L., Ogiso, T., Cabral, R., \& Ito, N. (1993). Enhancement by nonmutagenic pesticides of GST-P positive hepatic foci development initiated with diethylnitrosamine in the rat. Cancer Letters, 72(1-2), 59-64. https://doi.org/10.1016/0304-3835(93)90011-W

Huang, J., Tan, P. H., \& Thiyagarajan, J. (2003). Prognostic significance of Glutathione S-Transferase-Pi in invasive breast cancer. Modern Pathology, 16, 558-565. https://doi.org/10.1097/01.MP.0000071842.83169.5A

Ji, C., Magnuson, J. T., Zhang, W., \& Zhao, M. (2021). New insight into the enantioselective cytotoxicity of cypermethrin: imbalance between cell cycle and apoptosis. Journal of Hazardous Materials, 403, 123893. https://doi.org/10.1016/j.jhazmat.2020.123893.

Jörg, S., Grohme, D. A., Erzler, M., Binsfeld, M., Haghikia, A., Müller, D. N., Linker, R. A., \& Kleinewietfeld, M. (2016). Environmental factors in autoimmune diseases and their role in multiple sclerosis. Cellular and Molecular Life Sciences, 73(24), 4611-4622. https://doi.org/10.1007/s00018-016-2311-1.

Kakehashi, A., Inoue, M., Wei, M., Fukushima, S., \& Wanibuchi, H. (2009). Cytokeratin 8/18 overexpression and complex formation as an indicator of GST-P positive foci transformation into hepatocellular $\begin{array}{llll}\text { carcinomas. Toxicology } \quad \text { and } \quad \text { Applied } & \text { Pharmacology, 238(1), }\end{array}$ https://doi.org/10.1016/j.taap.2009.04.018

Kumar, P. V., Ahamed, A. J., \& Karthikeyan, M. (2019). Synthesis and characterization of NiO nanoparticles by chemical as well as green routes and their comparisons with respect to cytotoxic effect and toxicity studies in microbial and MCF-7 cancer cell models. SN Applied Sciences, 1(9), 1-15. https://doi.org/10.1007/s42452-019-1113-0

Kural, C., Kaya Kocdogan, A., Şimşek, G. G., Oğuztüzün, S., Kaygın, P., Yılmaz, I., Bayram, T., \& Izci, Y. (2019). Glutathione S-Transferases and Cytochrome P450 Enzyme Expression in Patients with Intracranial Tumors: 
Preliminary Report of 55 Patients. Medical principles and practice. International Journal of the Kuwait University, Health Science Centre, 28(1), 56-62. https://doi.org/10.1159/000494496.

Lark, A. L., Livasy, C. A., Calvo, B., Caskey, L., Moore, D. T., Yang, X., \& Cance, W. G. (2003). Overexpression of focal adhesion kinase in primary colorectal carcinomas and colorectal liver metastases: immunohistochemistry and real-time PCR analyses. Clinical Cancer Research, 9(1), 215-222.

Mathieu, A., Remmelink, M., D'Haene, N., Penant, S., Gaussin, J.-F., Van Ginckel, R., Darro, F., Kiss, R., \& Salmon, I. (2004), Development of a chemoresistant orthotopic human nonsmall cell lung carcinoma model in nude mice. Cancer, 101, 1908-1918. https://doi.org/10.1002/cncr.20571

Mendes, M., Sousa, J. J., Pais, A., \& Vitorino, C. (2018). Targeted Theranostic Nanoparticles for Brain Tumor Treatment. Pharmaceutics, 10(4), 181. https://doi.org/10.3390/pharmaceutics10040181.

Murray, G. I., \& Burke, M. D. (1995). Immunohistochemistry of drug-metabolizing enzymes. Biochemical Pharmacology, 50(7), 895-903. https://doi.org/10.1016/0006-2952(95)00136-N

Nabetani, M., \& Shintaku, H. (2018). New Strategy of Clinical Studies for Premature Babies with Ischemic Brain Damage. In: Cell Therapy for Perinatal Brain Injury pp.17-24, Springer, Singapore.

Nishimura, T., Newkirk, K., Sessions, R. B., Andrews, P. A., Trock, B. J., Rasmussen, A. A., Montgomery, E. A., Bischoff, E. K., \& Cullen, K. J. (1996). Immunohistochemical staining for glutathione S-transferase predicts response to platinum-based chemotherapy in head and neck cancer. Clinical Cancer Research, 2(11), 18591865.

Nishimura, T., Newkirk, K., Sessions, R. B., Andrews, P. A., Trock, B. J., Rusmussen, A. A., Montgomery, E. A., Bischoff, E. K., Hanigan M. H., \& Cullen, K. J. (1998). Association between expression of glutathioneassociated enzymes and response to platinum-based chemotherapy in head and neck cancer. ChemicoBiological Interactions, 111, 187-198.https://doi.org/10.1016/S0009-2797(97)00161-0

Okidi, R., Ogwang, D. M., Okello, T. R., Ezati, D., Kyegombe, W., Nyeko, D., \& Scolding, N. J. (2020). Factors affecting mortality after traumatic brain injury in a resource-poor setting. BJS Open, 4(2), 320-325. https://doi.org/10.1002/bjs5.50243.

Ostrom, Q. T., Adel Fahmideh, M., Cote, D. J., Muskens, I. S., Schraw, J. M., Scheurer, M. E., \& Bondy, M. L. (2019). Risk factors for childhood and adult primary brain tumors. Neuro-oncology, 21(11), 1357-1375. https://doi.org/10.1093/neuonc/noz123.

Ostrom, Q. T., Gittleman, H., Liao, P., Vecchione-Koval, T., Wolinsky, Y., Kruchko, C., \& Barnholtz-Sloan, J. S. (2017). CBTRUS Statistical Report: Primary brain and other central nervous system tumors diagnosed in the United States in 2010-2014. Neuro-oncology, 19(suppl. 5), 1-88. https://doi.org/10.1093/neuonc/nox158.

Park, J. H., de Lomana, A., Marzese, D. M., Juarez, T., Feroze, A., Hothi, P., Cobbs, C., Patel, A. P., Kesari, S., Huang, S., \& Baliga, N. S. (2021). A systems approach to brain tumor treatment. Cancers, 13(13), 3152. https://doi.org/10.3390/cancers13133152.

Rahilly, M., Carder, P. J., al Nafussi, A., \& Harrison, D. J. (1991). Distribution of glutathione S-transferase isoenzymes in human ovary. Journal of Reproduction and Fertility, 93(2), 303-311. https://doi.org/10.1530/jrf.0.0930303. 
Raza, H. (2011). Dual localization of glutathione S-transferase in the cytosol and mitochondria: implications in oxidative stress, toxicity and disease. The FEBS Journal, 278, 4243-4251. https://doi.org/10.1111/j.17424658.2011.08358.x

Rustoen, T., Moum, T., Wiklund, I., \& Hanestad, B. R. (1999). Quality of life in newly diagnosed cancer patients. Journal of Advanced Nursing, 29(2), 490-498. https://doi.org/10.1046/j.1365-2648.1999.00912.x

Sarasso, E., Agosta, F., Piramide, N., \& Filippi, M. (2021). Progression of grey and white matter brain damage in Parkinson's disease: a critical review of structural MRI literature. Journal of Neurology, 268(9), 3144-3179. https://doi.org/10.1007/s00415-020-09863-8.

Shang, W., Liu, W. H., \& Zhao, X. H. (2008). Expressions of glutathione S-transferase alpha, mu, and pi in brains of medically intractable epileptic patients. BMC Neurosci, 9, 67. https://doi.org/10.1186/1471-2202-9-67

Singh, R. R., \& Reindl, K. M. (2021). Glutathione S-transferases in cancer. Antioxidants, 10(5), 701. http://dx.doi.org/10.3390/antiox10050701.

Sohn, S. W., Jung, J. W., Lee, S. Y., Kang, H. R., Park, H. W., Min, K. U., \& Cho, S. H. (2013). Expression pattern of GSTP1 and GSTA1 in the pathogenesis of asthma. Experimental Lung Research, 39(4-5), 173181. https://doi.org/10.3109/01902148.2013.789572

Townsend, D. M., Findlay, V. L., \& Tew, K. D. (2005). Glutathione S-transferases as regulators of kinase pathways and anticancer drug targets. Methods in Enzymology, 401, 287-307. https://doi.org/10.1016/S0076-6879(05)01019-0

Wahid, M., Mahjabeen, I., Baig, R. M., \& Kayani, M. A. (2013). Expression of CYP1A1 and GSTP1 in human brain tumor tissues in Pakistan. Asian Pacific Journal of Cancer Prevention, 14(12), 7187-7191. https://doi.org/10.7314/APJCP.2013.14.12.7187

Wang, B., Wang, W., Zhu, Z., Zhang, X., Tang, F., Wang, D., Liue, X., Yanc, L. X., \& Zhuang, H. (2017). Mitochondrial serine hydroxymethyltransferase 2 is a potential diagnostic and prognostic biomarker for human glioma. Clinical Neurology and Neurosurgery, 154, 28-33. https://doi.org/10.1016/j.clineuro.2017.01.005

Wang, L., Chen, S., Ding, Y., Zhu, Q., Zhang, N., \& Yu, S. (2018). Biofabrication of morphology improved cadmium sulfide nanoparticles using Shewanella oneidensis bacterial cells and ionic liquid: For toxicity against brain cancer cell lines. Journal of Photochemistry and Photobiology. B, Biology, 178, 424-427. https://doi.org/10.1016/j.jphotobiol.2017.11.007.

Watson, R. R., \& Killgore, W. D. (Eds.). (2016). Nutrition and lifestyle in neurological autoimmune diseases: multiple sclerosis. Academic Press, Elsevier.

Wu, M., Chen, W., Chen, Y., Zhang, H., Liu, C., Deng, Z., Sheng, Z., Chen, J., Liu, X., Yan, F., \& Zheng, H. (2018). Focused ultrasound-augmented delivery of biodegradable multifunctional nanoplatforms for imagingguided brain tumor treatment. Advanced Science, 5(4), 1700474. https://doi.org/10.1002/advs.201700474.

Yin, Z. L., Dahlstrom, J. E., Le Couteur, D. G., \& Board, P. G. (2001). Immunohistochemistry of omega class glutathione S-transferase in human tissues. Journal of Histochemistry and Cytochemistry, 49(8), 983-987. https://doi.org/10.1177/002215540104900806 